\title{
Registration and Promotion of Monumental Olive Trees in Greece.
}

\author{
Koniditsiotis Stavros \\ Msc of Cultural Policy and Development, \\ Open University of Cyprus, Cyprus
}

\begin{abstract}
The history of the olive tree, its cultivation and its products is known for centuries. Some olive tree have survived over millennia and their history dates back to antiquity. In many cases, it is related to mythology and religion. The olive tree is associated with folk tradition, people's everyday life, and customs. In Greece, monumental olive trees are found in the Peloponnese, Crete, Euboea, Chios, Pelion and Attica. This paper explores and describes the particular morphological features such as shape, size, wood, cavities and age, as well as the cultural characteristics such as historical or religious events, myths and traditions that define an olive tree and characterize it as monumental. The main aim of our research is to examine the key position that monumental olive trees and their materialistic and symbolic manifestations consist a natural and cultural heritage as well. In this framework the study focuses on various key issues related to monumental olives trees and their natural, historical, social and cultural value.
\end{abstract}

Keywords: Monumental Olive Trees, Nature conservation monuments, Natural sites, Greek monumental Olive Trees, Cultural heritage of olive Trees.

\section{INTRODUCTION}

The present study is a part of a wider research on the value of the natural heritage and specially on ancient olives trees as natural monuments and cultural heritage of all Mediterranean regions. According UNESCO "natural features consisting of physical and biological formations or groups of such formations, which are of outstanding universal value from the aesthetic or scientific point of view; geological and physiographical formations and precisely delineated areas which constitute the habitat of threatened species of animals and plants of outstanding universal value from the point of view of science or conservation; natural sites or precisely delineated natural areas of outstanding universal value from the point of view of science, conservation or natural beauty" [1].

The main aim of our research is to examine the key position that monumental olive trees and their materialistic and symbolic manifestations consist a natural and cultural heritage as well. In this framework the study focuses on various key issues related to monumental olives trees and their natural, historical, social and cultural value.

Since ancient times, olive trees have been a means of covering various needs of people. Despite the time passing and human intervention, many olive trees have survived. These are the so-called monumental olive trees, which are distinguished for their massive surface, the caverns and their trunk. In our country the monumental olive trees are protected by the P.D. 1971. Various public or 
Koniditsiotis, S. (2020). Registration and Promotion of Monumental Olive Trees in Greece. Advances_in Social Sciences Research Journal, 7(4) 107-121.

private organizations are involved in their promotion and protection. An important role in this direction is played by local communities play an important role towards this direction with their traditions, and with the help of the citizens themselves. Many of them acknowledge the existence of monumental olive trees in their area and realize their importance, so they try to have an active role in their promotion and protection.

An olive tree must meet certain criteria to be considered monumental. These criteria are divided into two major categories, morphological and cultural characteristics. Tsaroucha [2] points out that the classification of a tree has raised strong concerns in the scientific community and local community. It is worth mentioning that the morphological characteristics of an olive tree include the shape and size of the trunk, the olive wood, the formation of its caverns and, finally, its age. The evaluation of an olive tree usually begins by measuring the perimeter of its trunk, which gives it some cultural texture. In addition, other tangible features play an important role in the evaluation of a tree. The tangible values of olive trees are visible and are usually calculated on the basis of measurable data. Tangible ones include the particular species of olive trees, the size combined with their age, the impressive shape of its trunk and anything else that can attract the attention of an observer. Finally, morphological characteristics may include species rarity and endangered species. Cultural characteristics include all the elements that relate the olive tree to the mythology, tradition, history and religion of a society. These characteristics are not quantifiable, but place the researcher in the broader time frame of the tree's existence, contributing to linking the past with the present and the future. In order to protect monumental olive trees effectively, it is important to understand how people perceive their importance to the local community [3]. This importance lies in their diverse values, namely cultural, symbolic, aesthetic, educational, scientific and spiritual. The benefit of these non-tangible values is that man comes closer to nature. However, some trees carry historical / mythological elements. The final judge, always taken into account for the designation of an olive tree as monumental, is always the olive tree itself and its character. The olive tree and its cultivation since its appearance, 50,000 years ago, are still part of the economic, religious, social, political and cultural life of an area. In the olive groves you meet long-lived olive trees, which can exceed a thousand years. These trees stand out morphologically for their size, their outer and bulky surfaces, their internal caverns and their trunk relief. Many olive trees are also culturally linked to the history, mythology, religion, traditions and culture of the local communities in which they are found. The combination of morphological and cultural characteristics of an olive tree contribute to its designation as a monument. The need to protect, promote and utilize monumental olive trees as a cultural heritage is important for the promotion and development of local communities [4].

\section{METHODOLOGICAL APPROACH - DATING METHOD}

This study is a case study, a diverse range of sources is searched in order to verify the results from multiple sources of data. It has been based on primary data, archives and the dating, but also on the study of existing bibliography.

Until the beginning of the 20th century, dating was based solely on historical methods. Various diaries and chronologies of ancient peoples were used that depicted their history in written monuments. The Romans used as basis the year of their emperors, the Greeks the first Olympic Games, Egypt, the Near East, and ancient China the dynasties of their emperors. The inscriptions also help us to date and relate findings to historical dates. The column of the Roman period, embedded inside the monumental olive tree Gortyn in Crete, places the presence of the tree in the 
Byzantine period (330-824 AD) or the Arab period (824-961 AD). This method has a disadvantage that is worth mentioning. Careful synchronization with events needs to be done carefully and all components for dating multiple findings should be studied. Dating by historical methods was the most important process for the researcher, but was revised with the discovery of positive dating with radioactive carbon dating [5-10] ${ }^{1}$.

In addition, the age of a tree can also be roughly calculated using elements of the perimeter or maximum radius of the tree, once the average growth rate of the tree has been determined. The rate of growth is determined by the variety of the tree and the climatic and nutrient conditions of the soil of the area where the tree was grown. This growth, as [16] states, ranges from 0 to $3 \mathrm{~mm} /$ year, although it is usually between $0.8-1.5 \mathrm{~mm} /$ year. For example, if the tree trunk has a radius $\mathrm{R}=150$ $\mathrm{cm}$ and its average annual growth rate is $\mathrm{r}=0.8 \mathrm{~mm} /$ year, then the age of the tree will be $\mathrm{T}=\mathrm{R} / \mathrm{r}$ $=1,500: 0.8=1,875$ years. The radius of the trunk is not easy to be determined because of its asymmetric growth and its curved surface. Studies in olive trees show that the trunk and the arms of the trees are rarely symmetrical, most often having a peculiar and polycentric shape, which is why this dating method also requires specialized knowledge [17].

Finally, to calculate the age of an olive tree we can also use the mathematical equation Gleichung, that is, $\mathrm{A}=26.87+99.7 \times \mathrm{P}[\mathrm{m}]$. In detail, $\mathrm{A}=$ age of the olive tree, $\mathrm{P}=$ olive tree circumference measurement and $[\mathrm{m}]=$ meters. For example, the monumental Liverani olive tree located in the Mill of Kalimassia Chios according to the Gleichung equation is: $A=26.87+99.7 \times 11.16 \mathrm{~m} .=1,139$ years [18-22].

\subsection{Inclusion criteria for monumental olive trees.}

An olive tree must meet certain criteria to be considered monumental. These criteria are divided into two major categories, morphological and cultural characteristics. The classification of the characteristics of the olives was first carried out in 1999 at the conference "Olive and Olive Oil from Antiquity to the Present" at the Megaron Academy of Athens. Specifically, [3] in his lecture "Monumental olive trees. Protection and exploitation" classified monumental olive trees based on their morphological and cultural characteristics.

\subsubsection{Morphological characteristics}

Olive tree (Olea Europea) is a subtropical evergreen plant that grows on a tree and thrives in arid and warm areas. It belongs to the Oleaceae family and has the main characteristic of longevity and fruiting. The olive trees in Greece cover an area of 7.5 million acres, of which 600,000 are organic. Greece ranks 3rd in the world in terms of olive oil production after Spain and Italy. In Greece, olive trees are found in the Peloponnese, Chios, Corfu, Crete, the Ionian Islands, Pelion, Euboea, Attica and in all areas with good weather [23].

\footnotetext{
${ }^{1}$ Tree dating is a modern technique that was spread in the first decades of the 20th century by American astronomer A. E. Douglas. Introduced in Europe in 1930, it is still a means of calculating and correcting dates with historical methods, but also an isolated modern method of absolute dating. The method is based on studying the growth of the tree's rings, which become narrower as it ages. The growth of the tree is affected by climate change. The first study was done in Arizona on a species of California pine cones and needles, Pinus aristata, aged 4,900 years. Using specimens from dead and living pines, E. Schulman and C. Wesley Ferguson created a chronological sequence from here until 6,700 BC. Tsagarakis [11] points out that tree dating cannot be applied to the olive tree because of the pits formed in its trunk [12-15].
} 
Koniditsiotis, S. (2020). Registration and Promotion of Monumental Olive Trees in Greece. Advances_in Social Sciences Research Journal, 7(4) 107-121.

\subsubsection{The shape and size of the trunk}

From the roots of the olive tree vascular systems branch, which through the trunk are joined by its arms and branches. These systems are interconnected and result in an asymmetric growth in the arms. The growth of the olive tree leads to the formation of a hard trunk with many grooves. Characteristic of the olive trees is the trunk relief, which presents many forms that sometimes resemble human organs. An example is the olive tree located on Vasilissis Sofias Avenue in Athens at the age of 1500, the relief of which resembles a human face [16].

\subsubsection{The olive wood}

The olive tree stands out for the growth of its thick and shallow roots, which penetrate into the sandy soil and rocks in search of moisture and nutrients. During its development it acquires a hard round and bumpy neck with rosettes. The variety of the olive, the environment in which it is grown and the way it is grown, are some of the factors that determine the height of its neck [11, 24-26].

\subsubsection{The formation of the caverns of the olive tree}

The olive tree, when infected with certain diseases, acquires small or large cavities, also known as caverns or hollows. These cavities are also formed by the decay of the inner dead wood of the trunk and therefore have different dimensions and shapes [27].

The presence of hollows does not substantially affect the olive tree during its development, but plays an important role in its breakage. Usually at the dead end of the trunk new trunks grow from the tree's neck. Monumental olive trees usually have very large caverns inside their trunk. A typical example is the 800-year-old monumental olive tree located in the village of Aglysides, Cyprus, where 35 students entered its cave [28-29].

\subsubsection{Cultural characteristics}

Cultural characteristics include all the elements that relate the olive tree to the mythology, tradition, history and religion of a society. These characteristics are not quantifiable, but place the researcher in the broader time frame of the tree's existence, contributing to linking the past with the present and the future. In order to protect monumental olive trees effectively, it is important to understand how people perceive their importance to the local community. This importance lies in their diverse values, namely cultural, symbolic, aesthetic, educational, scientific and spiritual. The benefit of these non-tangible values is that man comes closer to nature. However, some trees carry historical / mythological elements. The final judge, always taken into account for the designation of an olive tree as monumental, is always the olive tree itself and its character [16].

\subsection{Inclusion criteria in nature conservation monuments.}

In Greece, monumental olive trees are protected by Legislative Decree 996 of 1971. According to Article 78, national parks, aesthetic forests and nature monuments are protected. Monuments of nature are characterized by all public and non-public lands, which are of particular paleontological, geomorphological and historical importance. Also, trees or clusters of trees, wetlands and rare plant species, which are of particular botanical, phytogeographical, aesthetic and historical importance, may be designated as nature monuments [30]. 
It is worth mentioning that the Greek Center for Biotopes - Wetlands [31] points out that 51 preserved nature monuments have been declared in Greece to date. These monuments cover a total area of 168.4 million square meters.

From December 2018 to April 2019, exploratory and descriptive research was conducted on monumental olive trees located in Greece, namely Kalamata, Nafplio, Salamina, Lesvos, Chios, Chania, Ierapetra, Corfu and Athens for five months. The purpose of this research was to examine and evaluate the particular characteristics of monumental olive trees and their ways of promotion [32]. In Athens, Kalamata and Chios, some of the key features of the monumental olive trees were measured with the collaboration of an agronomist and philologist to calculate the age and identification of the data with the bibliography, and photographic material was collected at the sites where the monuments are located.

\subsection{Case studies in Greece}

\section{THE CASE STUDY OF GREEK MONUMENTAL OLIVE TREES}

There are several monumental olive trees in Greece, in almost all areas where olive trees are grown. It is noteworthy that very few of them have been identified and reported in the literature. There are also some old olive trees that are related to ancient myths and have been mentioned in ancient texts, such as Athena's Olive, Plato's Olive and Peisistratos Olive [33]. Monumental olive trees in Greece exist in areas of Crete, Chios, Lesvos, Kalamata, Athens, Kefalonia, Delphi, Corfu, Ermioni, Salamis and other areas. These olives are related to the wider historical and religious context of the area in which they are located and have many special morphological features. This thesis presents some of the old olive trees of Greece and some important monuments. The olive trees were selected based on their cultural and morphological characteristics. The olives of Athens and Salamis are linked to the history of Greece and that is why it is important to mention them. From Crete were selected to present typical examples of monumental olive trees from each county, which have been recorded by Association of Crete Olive Municipalities. The Arcadia olive tree is a typical example of a monumental olive tree that has been stolen, while the olive tree of Xiropotamos in the Municipality of Kalamata is monumental olive trees that have not been studied or registered for their promotion, protection and promotion.

Historians Herodotus (485-410 BC) and Apollodorus Athenaeus (180-110 BC) mention in their texts the first olive tree, the Athena's Olive, which is related to its myth dispute between the goddess Athena and Neptune over the name of the city of Athens. According to legend, during the conflict between Athena and Neptune, Neptune struck the Acropolis with its trident. Then he pulled out of the land the first horse and discovered seawater, the gifts of God, which would give Athens its sovereignty over land and sea. Athena offered the first olive tree as a gift because there were no olives at that time. This controversy made goddess Athena victorious. The goddess's olive tree was located in the Pandrosian temple at Erechtheion and was the symbol of the city. Stamatopoulou [34] mentions that this olive was the calm olive tree of Athens and was offered during the reign of Kekropas. This olive tree is not preserved today [35-37].

There was an olive tree on the Sacred Road in the Botanical Garden called Plato's Olive Tree. This olive tree is said to have been taught by the philosopher Plato. According to legend, this olive tree must have been one of the Academy's twelve olives, which corresponded to the twelve gates. These twelve trees, as Klontza [38] mentions, were copies of the Sacred Olive that Athena had made as a 
Koniditsiotis, S. (2020). Registration and Promotion of Monumental Olive Trees in Greece. Advances_in Social Sciences Research Journal, 7(4) 107-121.

gift and were in Erechtheion during her conflict with Neptune. In 1975 the tree was uprooted due to a bus collision. The remainder of the trunk was transferred to the Agricultural University of Athens (AUA) in order to protect and exploit it. In 2013, the trunk section was stolen from AUA. The local community reacted strongly to the lack of a fence and an information board for the protection of the olive tree [16].

In the Municipality of Platanias of the Regional Unity Chania Crete there is the monumental "Tall Olive" Vatolakkou. This olive tree is the only one of its kind, as the rest of the "highlands" in the area have disappeared. According to tradition, these olive trees protected the area from disease and wars. The approximate age of 2,000 years, combined with its special embossed body and local religious traditions, constituted the criteria for declaring it a monumental by ACOM. The olive tree belonged to Anna Galanaki, who made the concession to the Municipality of Platanias in order to protect and promote it. The variety of the fruit is tsunati and has been vaccinated in wild olives. The trunk has several grooves and holes, which are traditionally associated with old religious ceremonies. The circumference of the trunk at the base is $9.50 \mathrm{~m}$ and its diameter varies between $2.50 \mathrm{~m}$. and $3.10 \mathrm{~m}$. Galanakis [29] mentions that the priest of the village dug holes in the trunk of the olive tree, where the faithful used to place offerings, incense and other holy things. These holes were then closed with a lid giving the olive tree a sanctuary and respect by all the inhabitants of the village. It is noteworthy that some tried to cut the tall olive tree, but to no avail, because the saws were broken during cutting. Signs are now visible from the slit of the saw [40].

The "Mother Olive" of Kamilari is located in the "Two Lacs" in the Municipality of Phaistos of the Regional Unity Heraklion Crete and has been declared a monument by ACOM due to its location next to archaeological sites. The olive tree is approximately 2,800 years old and dates back to the Roman period (67 BC - $330 \mathrm{AD}$ ). The perimeter of the trunk at the base is $9.50 \mathrm{~m}$. and its diameter is between $3.05 \mathrm{~m}$ and $3.25 \mathrm{~m}$. The Kamilari Cultural Association placed 12 large stones around the trunk aiming to mark and protect the olive tree. It is only 1,400 meters away from the Minoan Palace of Phaistos and $1.000 \mathrm{~m}$ from the vaulted Minoan tomb of Kamilari. The olive tree belongs to Catherine Nicolidakis and is a species of Thrombolia inoculated in Wild Olive [5].

So far there have been references to monumental olive trees that are mainly related to the history and religion of the area. It is worth mentioning an olive tree that is connected with the history of the area and with an ancient olive grove. This is the monumental olive tree of Amari in the municipality of Amari of the regional unity Rethymno Crete. The olive tree has particular morphological features, is located near the Minoan settlement of Monastiraki and is part of the ancient 500-acre olive grove. In 1980 monumental olive trees were eradicated in the olive grove due to low productivity. Today, two olive trees owned by Dimitrios Kamilaki, aged 3,000 and 3,100 years respectively, are preserved and date back to the Sub-Minoan period (1,100-1,000 BC). Their morphological features are particularly noteworthy, as the perimeter of their base trunk varies between $18.80 \mathrm{~m}$. and $19.40 \mathrm{~m}$. The variety of these olives is thrombolite [5].

An important monumental olive tree with a long history is the monumental Olive Tree in Salamis. It is located on Kakiviglas Avenue in the town of Aiantio Salamina. According to the Klorane Institute, the age of the olive tree is estimated at 2,500 years. It has a trunk perimeter at the base of $12 \mathrm{~m}$, while the central trunk has a perimeter of $5.70 \mathrm{~m}$. with a variety of thick fruit. Apart from the particular morphological features, the Orsa Olive is associated with a legend and with the history of 
Salamis. The legend refers it that the olive tree was a dowry of Orsa, a girl who lived in Salamis in the 17th century. Orsa, married, fell in love with a Turk. To revenge her wife, the husband decapitated her and placed her head on a pair. The story of the olive tree, as stated in the oral tradition, relates to the tyrant of Athens Peisistratos, who may have planted this olive tree in Salamis [41-43].

The olive tree of Koutroufoi, located in the Neochori area of the Municipality of North Kynouria, regional unity Arcadia is a typical example of a monumental olive tree that was stolen. The olive tree comes from the plain of Thirea, which was a well-known olive grove since antiquity. The age of the olive tree is estimated at 2,500 years with a trunk circumference at the base of $11 \mathrm{~m}$. This olive tree is associated with the legends and traditions of the region. On February 23, 2010, the olive tree was arbitrarily uprooted by the tenant of the site, who, after working with a Kranidi contractor, sold it overseas. The Local Council, in cooperation with the Cultural Association and the villagers, immediately mobilized and prevented the transfer of the monumental olive tree. Two days later the olive tree was transplanted to the central square of the village for its protection and protection [4445].

Last but not least, the monumental olive tree located in the area of Xiropotamos in the Municipality of Kalamata. Messinia. The circumference of the trunk at the base is $7 \mathrm{~m}$. while the circumference of the trunk at a height of $80 \mathrm{~cm}$ from the ground is $8.20 \mathrm{~m}$. The variety of the fruit is reed inoculated in wild olive. According to Gleichung's mathematical act the approximate age of the olive tree is 1,037 years. It is owned by George Dantis and is associated with social events. According to the owner, this olive tree was the first olive planted on this estate and was dedicated to Saint George. Every year on the feast day of Saint George social events were held in the estate in the presence of all the locals.

Table 1: Case studies in Greece.

\begin{tabular}{|c|c|c|c|c|c|c|c|}
\hline \multirow{2}{*}{ Location } & \multicolumn{5}{|c|}{ Inclusion criteria for monumental olive trees } \\
\cline { 2 - 7 } & Morphological & Aesthetic & Historical & Cultural & Touristic & Ecological & Botanical \\
\hline $\begin{array}{c}\text { "Athena's Olive", } \\
\text { Acropolis of } \\
\text { Athens }\end{array}$ & & & $\mathbf{X}$ & $\mathbf{X}$ & & & \\
\hline $\begin{array}{c}\text { "Plato's Olive", } \\
\text { Sacred Road in } \\
\text { the Botanical } \\
\text { Garden Athens }\end{array}$ & & & & & & & \\
\hline $\begin{array}{c}\text { "Tall Olive", } \\
\text { Vatolakkou in } \\
\text { regional unity } \\
\text { Chania Crete }\end{array}$ & $\mathbf{X}$ & & $\mathbf{X}$ & $\mathbf{X}$ & & & \\
\hline $\begin{array}{c}\text { "Mother Olive", } \\
\text { Kamilari }\end{array}$ & & & $\mathbf{X}$ & & & & \\
$\begin{array}{c}\text { Phaistos in } \\
\text { regional unity }\end{array}$ & $\mathbf{X}$ & & & & & & \\
Heraklion Crete & & & & $\mathbf{X}$ & & & \\
\hline
\end{tabular}


Koniditsiotis, S. (2020). Registration and Promotion of Monumental Olive Trees in Greece. Advances_in Social Sciences Research Journal, 7(4) 107-121.

\begin{tabular}{|c|l|l|l|l|l|l|}
\hline $\begin{array}{c}\text { Olive tree Amari } \\
\text { in regional unity } \\
\text { Rethumno Crete }\end{array}$ & $\mathbf{X}$ & $\mathbf{X}$ & & & & \\
\hline $\begin{array}{c}\text { "Orsa's Olive", } \\
\text { Kakiviglas } \\
\text { Avenue in } \\
\text { Aiantio Salamina }\end{array}$ & $\mathbf{X}$ & $\mathbf{X}$ & & & & \\
\hline $\begin{array}{c}\text { "Olive tree of } \\
\text { Koutroufoi" in } \\
\text { region unity } \\
\text { Arcadia }\end{array}$ & $\mathbf{X}$ & $\mathbf{X}$ & & & & \\
\hline $\begin{array}{c}\text { Olive tree in } \\
\text { Xilopotamos, } \\
\text { Kalamata }\end{array}$ & $\mathbf{X}$ & & $\mathbf{x}$ & & & \\
\hline
\end{tabular}

\subsection{Nature monuments}

The first olive tree declared a monument of nature is the olive tree of Nafplio. It is located in the city's Panagia Square and has remarkable morphological, aesthetic and historical features. According to oral tradition, on 1 February 1655, the Turks hanged Saint Anastasios, who is also the patron saint of the city [46].

Also, in the same ministerial decision, a cluster of 8 olive trees located on the farm of the Holy Monastery of Taxiarches in Dimaini, Argolidas, were designated as nature monuments. These olives are of religious value and are linked to the historical events of the area. Ibrahim did not destroy these trees because they were identified with Turkish firman as a wakfu section, that is, the Sacred Forest [47].

In addition, three centuries-old olive trees over 200 years old, located on the outskirts of the Church of the Assumption, in the beach settlement of Almyropotamos - Karyotia, have been declared monuments of nature. These olives have particular morphological characteristics, a perimeter of more than 6.30 meters and give an aesthetic presence to the area. The growing tourist movement of the area played an important role in proclaiming them as monuments of nature [31].

The next decision to declare a historic and centuries-old olive tree in nature's monuments came in 1980. According to No. 200995/7950/19.12.1979 paragraph 3 ministerial decision, the centuriesold olive tree, representative of the Kalamata Olive variety, located in Kalamata, is 800-850 years old, 14 meters high and circumference of trunk 9 meters. According to Katsaris [48], there are eight people inside the olive tree. In addition to its interesting morphological and cultural characteristics, this "mother" olive tree is associated with the history of the area. The olive tree was saved in 1827 from the burning of 25,000 olive trees by the Ibrahim troops [49].

It is also worth mentioning the decision of the Secretary General of the Region of Crete, according to which the olive tree in the settlement of Pano Vouves, in Kissamos Prefecture of Chania, was declared a monument of nature. The tree is 22 meters high and belonged to Panagiotis Karapatakis, who gave it to the Municipality of Kolymvari. The variety of the fruit is tsunati and has been vaccinated in wild olives. The tree dates back to 3,000-5,000 years and is considered to be the oldest tree in the world. In addition to the age of the tree, its embossed trunk features spiral protrusions 
reminiscent of faces. It is worth mentioning that in the large inner cavern of the olive tree there is enough space for many individuals. Alalou [50] reports that more than 20,000 people visit the Monumental Olive Tree every year. The perimeter of the trunk is 12 meters, has a base surface of 11.45 sq.m. and diameter 3.64 meters. Also, during the 2004 and 2008 Olympic Games in Athens and Beijing respectively, with a twig out of the mute tree, the first marathon winner was crowned. Finally, on October 31, 2010, the winners of the Classic Marathon at the Kallimarmaro Stadium in Athens [51-55].

Another olive tree that declared a monument of nature is the olive tree found in Agioi Anargyroi, Attica, also known as the Peisistratos Olive (Ministerial Decision 2112/96 (Government Gazette 341 / B / 1999). The olive tree, which according to Michelakis [16] is over 2,500 years old, is located in front of the church of Agioi Anargyroi, with extra morphological features and culturally, as it is thought to have originated from the olive grove of Peisistratos (560-527 BC) [27]. Houstoulakis [56] points out that the tyrant of Athens Peisistratos took branches from the olive tree planted by the goddess Athena in the Erechtheion of the Acropolis in order to make his olive grove.

According to the Decree 73490/2018 of the Decentralized Administration, Peloponnese, Western Greece and the Ionian Sea, the "Olive of St. Spyridon Panachoritis" in Argyrades, Corfu, was declared a nature preserve. The age of the olive tree has not been determined yet, but according to the method of the rings and the maximum diameter they have used for dating olive trees in Crete, it is estimated at around 2,700 years. This olive tree has special botanical, ecological, aesthetic, historical and cultural value and is a valuable pedagogical and educational reference point of the island. According to the decision, the surface of the trunk stand is 12.45 square meters and the perimeter of the tree at the base of the trunk is 21.66 meters. The largest trunk diameter is 4.35 meters and the smallest is 0.55 meters. In the olive tree the primary subject olea sylvestris (olive or forest olive), the parent plant Olea europea - sunflower on which the variety olea europea - lianolia has been vaccinated co-exist. Historically, Elia and with the nearby church of Agios Spyridon lived many historical events. According to theologian Theophanes Kavadia, this olive tree was planted in the Byzantine era. According to the tradition near the olive tree in the churchyard, the fighters from Argyrades took part in the last Turkish-Venetian war of 1716. Also, in 1816 many locals died of the plague and were buried in the site of the olive tree. To the west of the olive tree we are two plaques with the inscription: " Tomb of the Abandoned Abandoned". The Corfu people attribute their salvation from the plague to Saint Spyridon, patron of the island [57].

In the Municipal Apartment Azoria - Kavousiou of Ierapetra Municipality of Crete Lassithi is the monumental ancient olive tree of Kavousiou. It is the last olive tree that has been designated as a protected formation and in particular as a conservation monument of nature (Document 2951/1308-2019 of the Department of Environment and Spatial Planning of the Region of Crete). The Region document clearly states all the conditions and measures that must be taken to preserve and protect the ancient olive tree. The age of the tree is approximately 3,250 years. The circumference of the trunk at the base is $22.10 \mathrm{~m}$, while its diameter varies from $4.70 \mathrm{~m}$ to $7.10 \mathrm{~m}$. The morphological characteristics of the olive tree in combination with the location in which it is located are sufficient for its characterization as monumental. It is located near the ancient settlements "Vrontas", "Kastro" and "Azoria" and dates from the Late Minoan III (1200-1100 BC) to the Archaic period (1350-500 BC). Until 2008 the olive tree was owned by Grammatikakis Georgios, who gave it to the Municipality of Ierapetra. It is a tsunati variety inoculated in wild olives $[5,28,58)$. 
The choice of trees declared as nature monuments is mainly based on historical and cultural features. There is also the case of olives in the Almyropotamos-Karyotia community, for which tourism has been instrumental in declaring them monumental. The recording should be based on a combination of both the morphological and the cultural characteristics of the olive trees. There are several olive trees in Greece, which, while classified as monumental, have not been legally declared monuments of nature. In addition, declaring an olive tree as a monument helps to protect and promote not only the tree itself but also the area in which it is located. Local communities are informed about the existence and importance of the nature monument in their area. It is noteworthy that the sources of information on olive trees are mostly based on oral tradition without the ability to identify and document properly through literature.

Table 2: Nature monuments.

\begin{tabular}{|c|c|c|c|c|c|c|c|c|}
\hline \multirow{2}{*}{ Location } & \multirow{2}{*}{ Year } & \multicolumn{7}{|c|}{ Inclusion criteria in nature conservation monuments } \\
\hline & & Morphologic & Aesthetic & Historical & Cultural & Touristic & Ecological & Botanical \\
\hline Panagia Square, Nafplio & 1977 & $\mathbf{X}$ & $\mathbf{X}$ & $\mathbf{X}$ & & & & \\
\hline $\begin{array}{c}\text { Holy Monastery Taxiarches in } \\
\text { Dimaini, Argolida }\end{array}$ & 1977 & & $\mathbf{X}$ & $\mathbf{X}$ & & & & \\
\hline $\begin{array}{c}\text { Church of Assumption, beach } \\
\text { settlement Almyropotamos - } \\
\text { Karyotia }\end{array}$ & 1977 & $\mathbf{X}$ & $\mathbf{X}$ & & & $\mathbf{X}$ & & \\
\hline "Mother Olive Tree", Kalamata & 1980 & & & $\mathbf{X}$ & $\mathbf{X}$ & & & \\
\hline $\begin{array}{l}\text { Pano Voubes, Kissamos Prefecture } \\
\text { of Chania }\end{array}$ & 1997 & $\mathbf{X}$ & $\mathbf{X}$ & $\mathbf{X}$ & $\mathbf{X}$ & & $\mathbf{X}$ & \\
\hline $\begin{array}{c}\text { Peisistratos olive tree, Agioi } \\
\text { Anargyroi Attica }\end{array}$ & 1999 & $\mathbf{X}$ & $\mathbf{X}$ & $\mathbf{X}$ & $\mathbf{X}$ & & & $\mathbf{X}$ \\
\hline $\begin{array}{c}\text { Olive of St. Spyridon } \\
\text { PanachoritiArgyrades Corfu }\end{array}$ & 2019 & $\mathbf{X}$ & $\mathbf{X}$ & $\mathbf{X}$ & $\mathbf{X}$ & & $\mathbf{X}$ & $\mathbf{X}$ \\
\hline $\begin{array}{c}\text { "Ancient olive tree Kavousiou", } \\
\text { Lassithi Crete }\end{array}$ & 2019 & $\mathbf{X}$ & & & $\mathbf{X}$ & & & \\
\hline
\end{tabular}

\section{DISCUSSION OF THE RESULTS}

In the survey, 18 olive trees were categorized into two categories, nature conservation monuments and monumental olive trees. Almost all olive trees meet the criteria for inclusion in the UNESCO Natural Heritage List. "Athena's Olive" and "Plato's Olive", although fulfilling the criteria, cannot be included in the UNESCO Natural Heritage List because they do not exist today. The olive trees located in Crete are protected and promoted by the Association of Olive Municipalities of Crete ${ }^{2}$. The olive tree located at Vasilissis Sofias Avenue in Athens is protected by the Municipality of Athens and is in a flowerbed with plants and lawn. In Aglysides Cyprus the monumental olive tree has been protected by natural fencing and information signs. Aglysides community has built a small museum of natural stone next to the olive tree for visitors. An important exhibit of the museum is an old olive

\footnotetext{
${ }^{2}$ Since 2001 the Association of Olive Municipalities of Crete, which is active in Crete, has been involved in the study, protection and promotion of monumental olive trees. Twenty-five olive trees have been recorded in Crete to date. Since its inception, the Crete Olive Municipalities Association has appointed an interdisciplinary team, consisting of an archaeologist, agronomist and teacher, to evaluate the information gathered from each olive tree. Each tree that meets the standards set by the interdisciplinary team is classified and prefers to be classified as monumental. Then follows the construction and installation of information signs in Greek and English, as well as the reinforcement of the road network with signboards. In addition, monumental olive trees are restored, maintained and fenced, which is compatible with the particular environment in which they are located. Typically, stone walls, wooden piles and a natural rope are installed.
} 
mill, which first opened to the community in 1947 [29]. Orsay's olive tree in Salamis is not protected by a fence and a signboard and visitors can visit it by searching the internet. The olive tree of Koutroufoi in Arcadia is located in the central square and you are protected by the cultural association and the inhabitants of the village. The olive tree located in Panagia Square in Nafplio is protected by fencing and is immediately accessible to everyone. The "Mother Olive" in Kalamata located on a plot of the University of the Peloponnese protects you with a fence and information sign and is accessible to everyone. The Environmental Education Center of Kalamata regularly visits the olive tree in the framework of its educational programs. Peisistratos' olive tree in Agioi Anargyroi Attica is protected by fencing and is often visited by schools for study in the context of environmental education. The olive trees located in Taxiarches Monastery in Argolis are in a sacred place and are protected by the Monastery. Access to the olive trees is subject to permission from the Monastery. The operators of Argyrades, with the assistance of the Department of Forests, are conducting a study of the landscaping, protection and promotion of the olive tree of Agios Spyridonos Panachoritis in Corfu. Finally, the olive tree located in the area of Xiropotamos Kalamata is not protected because it is privately owned and has not been raised until today.

Table 3: Olive trees that meet the criteria for inclusion in the World Heritage List of Unesco.

\begin{tabular}{|c|c|c|c|c|c|c|c|c|c|c|}
\hline \multirow{2}{*}{ Location } & \multicolumn{10}{|c|}{$\begin{array}{l}\text { Criteria of selection of a monument or site to be included in the } \\
\text { World Heritage List }\end{array}$} \\
\hline & $\mathbf{I}$ & II & III & IV & $\mathbf{V}$ & VI & VII & VIII & IX & $\mathbf{X}$ \\
\hline Vasilissis Sofias Avenue Athens & & & & & & & & & $\mathbf{X}$ & \\
\hline Aglysides Cypros & & & & & $\mathbf{X}$ & & & & $\mathbf{X}$ & \\
\hline "Tall Olive" Vatolakkou Chania Crete & & & $\mathbf{X}$ & & & $\mathbf{X}$ & $\mathbf{X}$ & & $\mathbf{X}$ & \\
\hline "Mother Olive" Kamilari Phaistos Crete & & & $\mathbf{X}$ & & & $\mathbf{X}$ & $\mathbf{X}$ & & $\mathbf{X}$ & \\
\hline Amari Rethumno Crete & & & $\mathbf{x}$ & & & $\mathbf{X}$ & $\mathbf{X}$ & & $\mathbf{X}$ & \\
\hline $\begin{array}{l}\text { "Orsa's Olive" Kakiviglas Avenue Aiantio } \\
\text { Salamina }\end{array}$ & & & $\mathbf{X}$ & & & $\mathbf{X}$ & $\mathbf{X}$ & & $\mathbf{X}$ & \\
\hline "Olive tree of Koutroufoi" Arcadia & & & $\mathbf{x}$ & & & $\mathbf{X}$ & $\mathbf{X}$ & & $\mathbf{X}$ & \\
\hline Xilopotamos Kalamata & & & & & & $\mathbf{X}$ & & & $\mathbf{X}$ & \\
\hline Panagia Square, Nafplio & & & $\mathbf{x}$ & & & $\mathbf{X}$ & $\mathbf{X}$ & & $\mathbf{X}$ & \\
\hline $\begin{array}{c}\text { Holy Monastery of Taxiarches in Dimaini, } \\
\text { Argolida }\end{array}$ & & & $\mathbf{X}$ & & & $\mathbf{X}$ & & & $\mathbf{X}$ & \\
\hline $\begin{array}{c}\text { Church of the Assumption, Beach settlement } \\
\text { Almyropotamos - Karyotia }\end{array}$ & & & & & & & $\mathbf{X}$ & & $\mathbf{x}$ & \\
\hline "Mother Olive Tree" Kalamata & & & $\mathbf{x}$ & & & $\mathbf{X}$ & $\mathbf{X}$ & & & \\
\hline Pano Voubes Kissamos Prefecture of Chania & & & $\mathbf{x}$ & & & $\mathbf{X}$ & $\mathbf{X}$ & & $\mathbf{x}$ & \\
\hline $\begin{array}{c}\text { "Olive tree of Peisistratos" Agioi Anargyroi } \\
\text { Attica }\end{array}$ & & & $\mathbf{X}$ & & & $\mathbf{X}$ & $\mathbf{X}$ & & & \\
\hline ive of St. Spyridon Panachoritis" Argyrades Cor & & & $\mathbf{X}$ & & & $\mathbf{X}$ & $\mathbf{X}$ & & $\mathbf{X}$ & \\
\hline $\begin{array}{l}\text { "Ancient olive tree of Kavousiou" Lassithi } \\
\text { Crete }\end{array}$ & & & $\mathbf{x}$ & & & $\mathbf{X}$ & $\mathbf{X}$ & & & \\
\hline
\end{tabular}


Koniditsiotis, S. (2020). Registration and Promotion of Monumental Olive Trees in Greece. Advances_in Social Sciences Research Journal, 7(4) 107-121.

The protection and promotion of olive trees has proven to be an important pillar for the country's cultural heritage. But research should not stop there. Local communities should be made aware of and understand the importance of the culture of these olive trees to the history and traditions of their land. Initially, the local communities and associations that operate in them should, with the help of interdisciplinary teams of archaeologists, agronomists and philologists, record all olive trees locally and form complete dossiers with all the necessary information for each olive tree. Government agencies should then be interested in and support the inclusion of these olive trees in the list of protected nature monuments.

Finally, the process of registering olive trees in the National Inventory of Intangible Cultural Heritage should begin immediately. The National Inventory aspires to be a valid and up-to-date image of Greece's intangible cultural heritage by offering communities, groups and individuals the opportunity to share their own cultural experiences with local and international audiences, to talk about their collective identity, formulate proposals for the study, and especially for the preservation of their intangible cultural heritage [59].

\section{Funding}

This research received no specific grant from any funding agency in the public, commercial or for non-profit sectors and was held for the purpose of my postgraduate thesis entitled "Monumental Olive Trees. Their Protection and Promotion".

\section{References}

[1]. Unesco, "World Heritage Policy Compendium" [pdf], 1972. Available at:

http://whc.unesco.org/en/compendium/?action=theme\&id_theme=1,2,3,4,5,6 (accessed 24-03-2019).

[2]. Tsaroucha, E., Analysis and evaluation of the landscape of ancient olive groves in the Mediterranean. Protecting, preserving and promoting them as protected areas, Postgraduate Thesis, 2011, Thessaloniki: Aristotle University of Thessaloniki Department of Architecture - School of Agriculture Interdisciplinary Postgraduate Program in Landscape Architecture.

[3]. Michelakis, N., "Monumental olive trees. Protection and exploitation". Kamilakis P. and Karapidakis L. (ed.). Olive and Olive Oil from Antiquity to the Present, Proceedings of the International Conference 1-2 October 1999, Megaron Academy of Athens, 2003b, pp. 321-330. Athens: Hellenic Folklore Research Center of the Academy of Athens.

[4]. Kostenelos, D.G., "The Path of the Olive Tree Through the Centuries." Lexigram - Hadjievstratiou, E. (Ed.) Encyclopedia of Olive Oil: Olive Oil, Axis Editorial, Athens, 2017, pp. 21-27.

[5]. Association of Crete Olive Municipalities (ACOM), Conservation and Proclamation of the Monumental Olive Trees of Crete, 2014, Crete: Association of Crete Olive Municipalities (ACOM).

[6]. Karalis, L., Environmental Archeology, 2005, Athens: Book Institute - A. Kardamitsa.

[7]. Papagiannis, D., "In the beginning... not the time. Dating and Chronology in Paleolithic Archeology. ", 1998, Archeology and Arts, ed. 68, pp. 71-73.

[8]. Renfrew, C. \& Bahn, P., Archeology: Theories, methodology and practical applications. Julia Karalis - Giannakopoulou (ed.), 2001, Athens: Book Institute - A. Kardamitsa.

[9]. Souvatzi, St., Archaeological data. Search - Dating - Sorting - Study, notes by ELP42: Archeology in the Greek Area, 20102011, Open University of Cyprus.

[10]. Turatsoglou, I., "Numismatic and Archeology". Grammatikopoulou, E. (Ed.) The historical course of the monetary unit in Greece, 2002, pp. 11-23. Athens: National Research Foundation. 
Advances in Social Sciences Research Journal (ASSRJ)

Vol.7, Issue 4, Apr-2020

[11]. Tsagarakis, G. S., The daily variation of olive tree diameter during the year, Postgraduate Thesis, 2012, Athens: Agricultural University of Athens Department of Agricultural Biotechnology Laboratory of Electron Microscopy.

[12]. Hölscher, T., Classical archeology. Basic knowledge, 2005, Thessaloniki: University Studio Press.

[13]. yritzis, G., Archeometry Dating Methods in Archeology, 1994, Athens: Kardamitsa.

[14]. Striker, L. Cecil., What is dendrochronology? A brief introduction for archeologists and historians of art and architcture, 2010, Thessaloniki: Hellinic Ministry of Culture and Tourism $9^{\text {th }}$ Ephorate of Byzantine Antiquities.

[15]. Touloumis, K., Before history: an introduction to Prehistoric Archeology, 1999, Thessaloniki: Vanias.

[16]. Michelakis, N. (ed.), "Monumental Olive Trees in the World, Greece and Crete". Michelakis, N. (ed.) Olive and Oil in Crete, Proceedings of the International Symposium Sitia 23-25 May 2002, 2003a, pp. 32-43. Crete: Association of Olive Municialities of Crete.

[17]. Michelakis, N. (ed.), Olive and Oil in Crete, Proceedings of the International Symposium Sitia 23-25 May 2002, Association of Olive Municipalities of Crete, Crete, 2003, pp. 32-43.

[18]. Anonymous, The clash of olives, 2016b. Available at: https://www.politischios.gr/koinonia/i-anametrisi-tis-elias (accessed 19-01-2019).

[19]. Lekakis, G., Two ancient trees of Chios, 2014. Available at: https://www.youtube.com/watch?v=ipwOITG4HwQ (accessed 31-12-2018).

[20]. Roufakis, B., "From the wonders of nature. In Chios the biggest olive tree and not only. In Memory of the Italian Botanist Paolo Liverani », Daphne, Doc. 14, Chios: "Daphne" Magazine, 2005, pp. 16-18.

[21]. Union of Ionian Islands (UII), Results of studies of the age of perennial olive trees in the village of Stroggily Corfu [pdf], (n.d.). Available at:

http://www.enosieptanision.gr/files/\%CE\%A4\%CE\%B5\%CE\%BB\%CE\%B9\%CE\%BA\%CE\%AE\%20\%CE\%88\%CE\%BA\%CE\%B8\%CE \%B5\%CF\%83\%CE\%B7\%20\%CF\%84\%CE\%BF\%CF\%85\%20\%CE\%AD\%CF\%81\%CE\%B3\%CE\%BF\%CF\%85.pdf (accessed 24-032019).

[22]. Vahaviolos, D. and Saranti, A., The olive tree and its products. Sustainability and Life of our country. Kalamata: Environmental Education Center of Messinia [pdf], 2016-2017. Available at: http://kpe-kal.mes.sch.gr/elianet/wp/wpcontent/uploads/2017/06/20170515 ta elaiodentra tou gerakiou.pdf (accessed 06-10-2018).

[23]. Adriano del Fabro, Olive varieties - cultivation - products, 2009. Athens: Psichalou.

[24]. Anonymous, The Olive Tree, 2015. Available at: http://elialadi.blogspot.com/2015/09/to-dentro-tis-elias.html (accessed 19-01-2019).

[25]. Chartzoulakis, St. K. (ed.), "Following the Footprints of the Olive Tree in Greece". Following the Footprints of the Olive (Olea europaea L.), 2013, pp. 109-128. Chania: International Olive Counsil (IOC), International Society for Horticultural Science, Scripta Horticulturae N. 13 (ISHS), Association of Agricultural Research Institutes in the Near East and North Africa (AARINENA).

[26]. Fooks, R.,The book of Olive. Varieties - cultivation - plant protection - fruit harvesting \& processing, 2002, Athens: Psichalou.

[27]. Michelakis, N.,"Monumental Olive Trees in Greece and Crete". Provoli 4, 2000, pp. 23-38.

[28]. Social Cooperative Enterprise (SCE) Eptastikos, Cultural paths in perennial olive trees [pdf], (n.d.). Available at: http://eptastiktos.gr/wpcontent/uploads/2017/02/\%CE\%95\%CE\%BD\%CE\%B7\%CE\%BC\%CE\%B5\%CF\%81\%CF\%89\%CF\%84\%CE\%B9\%CE\%BA\%CF\%8C\%CF\%83\%CE\%B7\%CE\%BC\%CE\%B5\%CE\%AF\%CF\%89\%CE\%BC\%CE\%B1 \%CE\%95\%CE\%A0\%CE\%A4\%CE\%91\%CE\%A3\%CE\%A4\% CE\%99\%CE\%9A\%CE\%A4\%CE\%9F\%CE\%A3.pdf (accessed 08-03-2019).

[29]. Vasilas, P., 800 years of history in the shade of an olive tree, 2017.Available at: http://www.philenews.com/eidiseis/topika/article/466329/800-chronia-istorias-stin-koyfala-mias-elias (accessed 31-122018) 
Koniditsiotis, S. (2020). Registration and Promotion of Monumental Olive Trees in Greece. Advances_in Social Sciences Research Journal, 7(4) 107-121.

[30]. Douros, G., "Natural environment under pressure - The surviving remains of the once famous Attic landscape and their salvation". The Daily Seven Days - Attic Nature, 1999, pp. 8-10.

[31]. Greek Center for Biotopes - Wetlands (GCWW), Goulandris Museum of Natural History. Greek Center for Biotopes Wetlands, 2010. Available at: http://www.ekby.gr/ekby/el/EKBY PP el.html (accessed 24-03-2019).

[32]. Tsakiri, L., Introduction to Research Methodology [pdf], (n.d.). Available at: http://dpms.csd.auth.gr/stuff/eis-mether.pdf (accessed 20-03-2019).

[33]. Bofilias, A., "Highlighting the historic olive grove of Athens". Archeology and the arts, 2007, ed. 102, pp. 83-94.

[34]. Stamatopoulou G. B., "The appearance of olive in Greece according to tradition and its religious character." Kamilakis, P. and Karapidaki, L. (ed.) Olive and Oil in Space and Time, Minutes of the Symposium, Preveza 24-26 November 2000, 2003, pp. 45-56. Athens: Academy of Athens.

[35]. Faklaris, B. P. and Stamatopoulou, G.B., "Olive and oil in ancient Greece" in Kamilakis P. and Karapidaki L. (ed.). Olive and Oil from Antiquity to the Present, Proceedings of the International Conference 1-2 October 1999 Megaron Academy of Athens, 2003, pp. 33-47. Athens: Hellenic Folklore Research Center of the Academy of Athens.

[36]. Kourti, A.,"Old Kifissos Olives, Harmony Leaves. Jean Moreas, "Curves". The Olive Tree in Ancient Athens. From Moria Eleais to Plato's Olive Tree. " Michelakis, N. (ed.). Olive and Oil in Crete, Proceedings of the International Symposium Sitia 23-25 May 2002, 2003, pp. 77-85. Crete: Association of Olive Municipalities of Crete (ACOM).

[37]. Ropaitou-Tsapareli, E.Z., The Olive grove of Athens. Space and people over time, 2006. Athens: Philippoti.

[38]. Klontza, O., "The Sacred Olive Tree of Plato Became... Firewood" in To Vima, 2013. Available at: https://www.tovima.gr/2013/01/17/society/i-ieri-elia-toy-platwna-poy-egine-kaysoksyla/ (accessed 08-03-2019).

[39]. Galanakis, G., "The Tall Olive Tree in Vatolakkos", Chania News - Daily News of Chania, 2014.. Available at: http://www.haniotika-nea.gr/ipsomeni-elia-ston-vatolakko/ (accessed 06-10-2018).

[40]. Karapidaki, L. and Ifantis, Ar. P., "Uses and abuses of oil in Orthodox piety. Folklore and Theological Approach. " Kamilakis, P. and Karapidaki, L. (ed.) Olive and Oil in Space and Time, Symposium Proceedings, Preveza 24-26 November 2000, 2003, pp. 235-247. Athens: Academy of Athens.

[41]. Helmis, D., The Orsa Olive Tree: The 2500-year-old tree in Salamis that lived through the Great War of 480 BC, 2019. Available at: http://www.musioelias.gr/en/node/908 (accessed 20-03-2019).

[42]. Lekakis, G., Salamis Olive Dated 2500 years old, 2015. Available at: https://www.youtube.com/watch?v=97k6MksR1r4 (accessed 31-12-2018).

[43]. Trade Association of Salamis (TAS), The Olive Tree of Orsa, 2019. Available at: https://www.essalaminas.gr/\%CE\%B7\%CE\%B5\%CE\%BB\%CE\%B9\%CE\%AC-\%CF\%84\%CE\%B7\%CF\%82-\%CF\%8C\%CF\%81\%CF\%83\%CE\%B1\%CF\%82/ (accessed 24-032019).

[44]. Cultural Training Association of Koutroufs (CTAK), Interview with Dimitris Vlachou at ArcadiaVoiceGr for Olive 2011, 2013. Available at: https://www.youtube.com/watch?v=9zPDYzjPkdk\&fbclid=IwAR3tQnbKBXYI5kXHDDyenvZLCsZix4awK80r9IzF6KLZqIYiJERtbLaPoM (accessed on 24-02-2019).

[45]. Lekakis, G. Ancient robbers went to steal an ancient olive tree and sell it abroad!., (n.d.). Available at: http://www.arxeion-politismou.gr/2019/01/arxaiokapiloi-

elias.html?spref=fb\&fbclid=IwAR34EbWMRZ3mZW RAp5iblwyyEGnyklNidoj9w4 e63m B8TtfBNYi81WCM\&m=1 (accessed 31-12-2018).

[46]. Dasologoi.gr, Nature conservation monuments, 2017. Available at: https://dasologoi.gr/\%CE\%B4\%CE\%B9\%CE\%B1\%CF\%84\%CE\%B7\%CF\%81\%CE\%B7\%CF\%84\%CE\%AD\%CE\%B1\%CE\%BC\%CE\%BD\%CE\%B7\%CE\%BC\%CE\%B5\%CE\%AF\%CE\%B1-\%CF\%86\%CF\%8D\%CF\%83\%CE\%B7\%CF\%82/list/16 (accessed 06-04-2019).

[47]. Bousbouras, D., "The landscape of olive groves in the Peloponnese". Karagianni, O. (ed.) And the place ... oil. The presence of the olive tree in the Peloponnese, 2007, pp. 160-179. Athens: Piraeus Group Cultural Foundation. 
[48]. Katsaris, P., "The mother tree of the Kalamata olive tree (Olea europaea var. Ceraticarpa), in ELGO Dimitra, issue. 4, October - December 2013, 2013, pp. 4-5. Available at: http://www.elgo.gr/index.php/en/elgo-demeter-publications/elgopublications-demeter-magazine-past-issues/517-demeter-magazine-issue-03-2013 (accessed 26 -12-2018).

[49]. Frantzis, A., Epitome of the History of Regenerated Greece beginning in the year 1715, ending in 1835, vol. Second, 1839. Athens: Vittoria of Constantine Kastorchis and Companion.

[50]. Alalou, I., The Oldest Olive Trees, 2017. Available at: https://medium.com/@ibrahimaloua/the-oldest-olive-treesf75a09e53615 (accessed 10-04-2019).

[51]. "Anatoli" Industrial Company (AIC). (n.d.). Available at: https://www.abea.gr/olive-museum/ (accessed 19-012019).

[52]. Anonymous, The oldest olive tree in the world is located in Chania, 2016a. Available at: https://www.zougla.gr/perivallon/article/i-arxeoteri-elia-tou-kosmou-vriskete-sta-xania (accessed 19-01-2019).

[53]. Diaforetiko, In Crete one of the oldest trees in the world. 9,000-year-old olives still bearing fruit, 2018. Available at: https://www.diaforetiko.gr/stin-kriti-apo-ta-archeotera-dendra-ston-kosmo-elies-ilikias-9-000-eton-pou-vgazoun-akomakarpous/ (accessed 06-04-2019).

[54]. Karapataki, K., Museum of Olive Vouves, (n.d.). Available at: http://www.olivemuseumvouves.com/default.aspx?lang=el (accessed 04-04-2019).

[55]. Tsigounakis, B.C., "Trees. Live Monuments of Crete», Cretan Speech November 2017, 2017, page 140, p. 2. Athens: Tzigounakis.

[56]. Houstoulakis, G., The oldest tree in Attica!, 2018. Available at: https://www.cretanmagazine.gr/to-archaiotero-dentrotis-attikis/ (accessed 20-03-2019).

[57]. Anonymous, Corfu Preserved Monument of Nature proclaimed "Olive of Agios Spyridon" in Panahori Argyrades, 2019. Available at: https://www.startmediacorfu.gr/kerkyra-diatiriteo-mnimeio-tis-fysis-anakirychthike-i-elia-t-agiou-spyridonasto-panachori-argyradon/ (accessed 10-12-2019).

[58]. Papageorgiou. K., The three oldest olive trees in Europe, 2018. Available at: https://e-thessalia.gr/oi-treis-archaiotereselies-stin-eyropi/ (accessed 15-03-2019).

[59]. Courtyard of Heritage of Greece, "Purpose of the National Inventory of ICH", (n.d.). Available at: http://ayla.culture.gr/en/purpose/ 